\title{
POTENSI EKOWISATA DIKAWASAN TAMAN HUTAN RAYA (TAHURA) NIPA-NIPA DIKELURAHAN WATU-WATU
}

\author{
Isanto $^{1}$ \\ ${ }^{1}$ Program Studi Pendidikan Geografi, Universitas Halu Oleo, Kendari.
}

\begin{abstract}
This research aims to know the Potential of Ecotourism in Tahura NipaNipa Area in Watu-Watu Village. The type of this research is descriptive qualitative research. The aim is to get an overview of the ecotourism potential that is found in Kawasa Taman Hutan Raya (TAHURA) Nipa-Nipa. To get information from the researcher using the key informants. The informants in this research are determined based on the research needs. Data collection techniques used are through interviews, observation and documentation. Data obtained from 6 informants namely the Department of Tourism as much as 1 person, the Forest Service in this case Unit PelaksaTeknis Daerah (UPTD) as much as 1 person and the Community who live around Tahura Nipa-Nipa in Kelurahan Watu-Watu as many as 4 people. Based on the result of the research from the interview of the informant, the result of research is the Potential of Ecotourism in Tahura Nipa-Nipa Area in Watu-Watu Village in the form of Flora potency in the form of Ironwood, Bolo-bolo and others. For the type of fauna that exist in the form of monkey macaca endangered animals Sulawesi, some species of dragonflies and monitor lizards, in addition there are other promising ecotourism potential of natural attractions such as waterfalls, camping places. In the study there is also another potential in the area of Tahura Nipa-Nipa ie there is agricultural land managed by surrounding communities who are familiar with the farmers Subur Makmur
\end{abstract}

\section{Kata kunci :Potensi Ekowisata, Tahura Nipa-Nipa di Kelurahan Watu-Watu}

\section{PENDAHULUAN}

Kawasan konservasi baik
kawasan pelestarian alam maupun
Kawasan suaka alam atau kawasan
hutan lindung, merupakan
Destinasi yang diminati oleh
wisatawan ekotour, karena memiliki keanekaragaman flora dan fauna, fenomena alam yang indah, objek budaya dan sejarah serta kehidupan masyarakat local yang unik. Bisnis konservasi merupakan pemanfaatan kawasan hutan konservasi sebagai obyek kawasan wisata alam dalam pembangunan ekonomi tanpa merubah fungsi ekosistem lingkungan kawasan konservasi tersebut.Dapat dikatakan juga bahwa ekowisata merupakan konsep pariwisata yang sangat

$\begin{array}{llr}\text { alternatif yang } & \text { secara konsisten } \\ \text { mengedepankan } & \text { nilai-nilai } & \text { alam, } \\ \text { sosial, dan } & \text { masyarakat } & \text { yang } \\ \text { memungkinkan adanya } & \text { interaksi } \\ \text { positif antar-para pelakunya. } & \end{array}$

Kawasan konservasi baik kawasan pelestarian alam maupun Kawasan suaka alam atau kawasan hutan lindung, merupakan Destinasi yang diminati oleh wisatawan ekotour, karena memiliki keanekaragaman flora dan fauna, fenomena alam yang indah, objek budaya dan sejarah serta kehidupan masyarakat local yang unik. Bisnis konservasi merupakan pemanfaatan kawasan hutan konservasi sebagai obyek kawasan wisata alam dalam pembangunan ekonomi tanpa merubah fungsi ekosistem lingkungan kawasan 
konservasi tersebut.Dapatdikatakan juga bahwa ekowisata merupakan konsep pariwisata yang sangat alternatif yang secara konsisten mengedepankan nilai-nilai alam, sosial, dan masyarakat yang memungkinkan adanya interaksi positif antar-para pelakunya.

Ekowisata telah berkembang sebagai salah satu industri yang potensial untuk kepentingan pembangunan yang berkelanjutan.Ekowisata mempunyai kekhususan, yaitu mengedepankan konservasi lingkungan, pendidikan lingkungan dan menguntungkan penduduk lokal (meningkatkan perekonomian penduduk lokal).

Penyelenggaraan ekowisata pada dasarnya dilakukan dengan kesederhanaan, memelihara keasliaan alam dan lingkungan, memelihara keaslian adat istiadat, kebiasaan hidup, menjaga kelestarian flora dan fauna, serta melestarikan lingkungan hidup sehingga terjadinya suatu keseimbangan antara kehidupan manusia dengan lingkungan alam

Kendari merupakan ibu kota provinsi Sulawesi Tenggara. Secara geografis, kota Kendari terletak di sepanjang teluk Kendari, di wilayah timur Sulawesi Tenggara. Wilayah.

kendari sebagian besar berupa dataran berbukit yang di lalui oleh sungai-sungai yang bermuara di teluk Kendari. Sebagai ibukota Provinsi Sualwesi Tenggara memiliki luas wilayah sekitar 295,89 km persegi.

Kawasan taman hutan raya (TAHURA) terletak di pegunungan Nipa-Nipa yang berada di kota Kendari. Tahura Nipa-Nipa ini merupakan salah satu hutan yang dijadikan kawasan konservasi alam.

Taman Hutan Raya Nipa-Nipa merupakan salah satu kawasan pelestarian alam Provinsi Sulawesi
Tenggara seluas $7.877,5$ ha yang meliputi wilayah administrasi, Kota Kendari dan Kabupaten Konawe, Sulawesi Tenggara (BKSDA Sultra, 2002).

Kawasan Tahura Nipa-Nipa yang sebagian wilayahnya berada di Kota Kendari merupakan salah satu kawasan prioritas bagi pengembangan wisata di Kota Kendari.

Kawasan tersebut ditetapkan sebagai daerah pengembangan wisata karena memiliki potensi Sumberdaya Alam yang cukup besar maupun potensi wisata alam yang terdiri atas keanekaragaman hayati yaitu flora dan faunanya serta panorama alam yang indah dan menarik.Potensi Sumberdaya Alam tersebut dapat dijadikan sebagai Obyek Daya Tarik Wisata Alam yang dapat dikembangkan untuk menarik minat pengunjung ataupun wisatawan baik lokal maupun asing dan dapat memberikan pengalaman wisata yang variatif dengan atraksi yang unik dan menarik.

Ekowisata merupakan gerakan kesadaran wisata yang terkait dengan isu lingkungan yang mulai berkembang secara global.Ekowisata juga merupakan alternatif bagi kegiatan pariwisata yang bersifat massal dan ramai.

Hal ini timbul karena didasari kenyataan bahwa kegiatan pariwisata disamping memberikan manfaat bagi pertumbuhan ekonomi juga memiliki dampak ekologi yang memprihatinkan.Selain itu muncul pula masalah lingkungan sebagai akibat pembangunan yang bersifat eksploitatif dan akumulatif dapat dilihat dari gejala ketidakadilan antar warga, kesenjangan antar wilayah, degradasi sumber daya (air, hutan, lahan, kelautan), pencemaran, dan 
lain-lain (Mohhamad Baiquni, 2001: 132).

Fandeli (2000) memberi batasan ekowisata yaitu suatu bentuk wisata yang bertanggung jawab terhadap kelestarian area yang masih alami, memberi manfaat secara ekonomis dan mempertahankan keutuhan budaya bagi mayarakat setempat. Berdasarkan pengertian tersebut, bentuk ekowisata pada dasarnya merupakan suatu gerakan konservasi yang dilakukan oleh penduduk

Ekowisata dapat berkembang dengan pesat dikarenakan memiliki cara untuk menerapkan kegiatan wisata yaitu dengan pelestarian lingkungan sekitar, memberikan pengetahuan pada pengunjung wisata dan memberikan keuntungan secara ekonomi pada masyarakat setempat.

Beeton (2000) menyatakan bahwa pengertian ekowisata dapat ditinjau dari tiga unsur utamanya, yaitu:

1. Nature-based

Nature based berhubungan dengan flora dan fauna dari sebuah kawasan dan bisa diasosiasikan dengan lingkungan yang sudah dimodifikasi oleh manusia. Ekowisata hendaknya memberikan dampak sekecil mungkin terhadap alam (nature). Dampak kecil ekowisata, yaitu melalui manajemen lokal, ketentuan-ketentuan dalam kualitas travel product dan pengalaman wisata, memberlakukan nilai-nilai budaya, pelatihan dengan penekanan, tanggung jawab terhadap sumberdaya alam dan budaya, serta integrasi antara pembangunan dan konservasi.

\section{Educative}

Kebanyakan orang menginginkan pengalaman untuk dapat berwisata ke lokasi yang menyediakan informasi yang dapat membantu mereka untuk memahami daerah yang mereka datangi.Ekowisata haruslahbisa memberikan keterangan-keterangan penting tentang suatu kawasan.Ketersediaan keterangan/informasi tersebut sehingaa dapat memberikan peluang pembelajaran bagi para wisatawan yang berkunjung.

3. Sustainable Management

Ekowisata dan wisata harus memelihara keberlanjutan lingkungan, sebagai bagian dari pertimbangan tanggung jawab ke arah kelestarian lingkungan dimasa yang akan datang. Sustainable management artinya mengatur tekanan fisik lingkungan seperti jumlah pengunjung dan perilakunya, caranya adalah dengan memperkenalkan pengaruh buruk yang dapat ditimbulkan pengunjung terhadap lingkungan atau dengan menghemat penggunaan energi.

Ekowisata memiliki arti dari wisata yang berbasis pada pelestarian yang dapat menjaga keseimbangan antara lingkungan dengan kegiatan wisata yang dapat memberikan keuntungan pada masyarakat setempat. Komponen yang mendukung ekowisata:

Memberikan konservasi dan pelestarian pada alam sekitar

a. Mendukung perekonomian masyarakat setempat

b. Memberikan konsep baru pada bisnis pariwisata

c. Mengurangi dampak penggunaan sumberdaya alam yang tidak dapat diperbaharui

Manajemen ekowisata tidak hanya melihat kenampakan alam yang ada namun dalam 
perjalanannya dapat diperoleh pengetahuan dari lingkungan sekitar (Wood, Megan E, 2002: 11).

Pengertian wisata alam adalah objek wisata yang bukan buatan manusia tetapi memang terbentuk dari alam atau dengan kata lain objek wisata natural (alam) dan bukan buatan manusia.

Wisata Alam adalah sumber daya yang berpotensi dan berdaya tarik bagi wisatawan serta yang ditujukan untuk pembinaan cinta alam, baik dalam kegiatan alam maupun pembudidayaan (Soewantoro, 1997: 47). Jadi dapat disimpulkan bahwa wisata alam adalah kegiatan rekreasi dan pariwisata yang memanfaatkan potensi sumber daya alam yang natural dan bukan buatan manusia.

Obyek wisata Segala sesuatu yang menarik dan bernilai untuk dikunjungi dan dilihat disebut atraksi" atau lazim pula di kataobyek wisata. Atraksi-atraksi ini antara lain panorama keindahan alam yang menakjubkan seperti gunung, lembah, ngarai, air terjun, danau, pantai, matahari terbit, dan matahari terbenam, cuaca, udara dan lain-lain. Di samping itu juga berupa budaya hasil ciptaan manusia seperti monumen, candi, bangunan klasik,peningalan purba kala, musium budaya, arsitektur kuno, seni tari, musik, agama,adat-istiadat, upacara, pekan raya, peringatan perayaan hari jadi, pertandingan, atau kegiatan-kegiatan budaya, sosial dan keolahragaan lainnya yang bersifat khusus, menonjol dan meriah, (Pendit,2002.20).objek wisata dapat diartikan suatu usaha atau cara yang dilakukan untuk membuat segala sesuatunya lebih baik yang dapat dilihat dan dinikmati oleh manusia sehingga menimbulkan perasaan senang, dengan demikian akan menarik wisatawan untuk berkunjung. suatu objek wisata harus dapat menciptakan product style yang baik, diantaranya adalah:

1. Objek tersebut memiliki daya tarik untuk disaksikan maupun dipelajari.

2. Mempunyai kekhususan dan berbeda dari objek yang lainnya.

3. Tersedianya fasilitas wisata.

4. Dilengkapi dengan sarana-sarana akomodasi,telekomunikasi, transportasi dan sarana pendukung lainnya.

Marpaung (2002:) juga menerangkan bahwa objek wisata adalah dasar bagi kepariwisataan. Tanpa adanya objek wisata disuatu daerah kepariwisataan sulit untuk dikembangakan.karena wisatawan ingin mengunjungi serta mendapatkan suatu pengalaman tertentu dalam kunjungnanya. Di dalam bukunya Marpaung juga menerangkan bahwa terdapat dua kategori objek wisata, salah satu kategori objek wisata menurut Marpaung yakni objek wisata alam

potensi wisata adalah semua objek (alam, budaya, buatan) yang memerlukan banyak penanganan agar dapat memberikan nilai daya tarik bagi wisatawan. Oleh sebab itu, Janianton Damanik \& Helmut F.Weber didalam buku perencanaan ekowisata (2006:11) menjelaskan bahwa elemen penawaran wisata sering disebut triple A yang terdiri dari atraksi, akesibilitas, dan amenitas. Secara singkat atraksi dapat diartikan sebagai objek wisata yang memberikan kenikmatan kepada wisatawan.

Potensi wisata adalah semua objek (alam, budaya, buatan) yang memerlukan banyak penanganan 
agar dapat memberikan nilai daya tarik bagi wisatawan. Oleh sebab itu, Janianton Damanik \& Helmut F.Weber didalam buku perencanaan ekowisata (2006:11) menjelaskan bahwa elemen penawaran wisata sering disebut triple A yang terdiri dari atraksi, akesibilitas, dan amenitas. Secara singkat atraksi dapat diartikan sebagai objek wisata yang memberikan kenikmatan kepada wisatawan.

Dari pemahaman mengenai potensi ekowisata tersebut dapat disimpulkan bahwa potensi ekowisata terkait dengan penawaran wisata. Elemen penawaran wisata terdiri atas (Damanik dan Weber ,2006):

\section{Atraksi}

Atraksi dibedakan menjadi atraksi yang tangible dan intangible yang memberikan kenikmatan kepada wisatawan baik yang berupa kekayaan alam, budaya dan hasil buatan manusia.

2. Aksesbilitas

Cakupan aksesbilitas yang keseluruhan saran dan prasarana transportasi yang melayani wisatawan dari, ke, dan selama didaerah tujuan tujuan wisata.

3. Amenitas

Fungsi amenitas lebih kepada pemenuhan kebutuhan wisatawan sehingga seringkali tidak berhubungan lansung terkait dengan bidang pariwisata.

Pariwisata adalah semua tentang kenyamanan dan kesenangan, orang suka mengunjungi tempattempat dan peristiwa yang mampu membuat mereka berkesempatan untuk bersantai dan bersenangsenangan. Tempat-tempat dan acara menarik bisa seperti; alam, budaya atau buatan (situasi dan peristiwa buatan manusia).

Peneliti Latupapua (2008) dalam kajiannya tentang "Study Potensi Kawasan Dan Pengembangan Ekowisata Di Tual Kabupaten Maluku Tenggara". Dalam penelitiannya menyebutkan bahwa di Tual Maluku Tenggara potensi untuk dikembangkan sebagai ekowisata.

Adapun sebagai pertimbangan karena memiliki potensi aneka flora yaitu sekitar 11 sampai 20 jenis tumbuhan hal ini akan menambah daya tarik wisatawan untuk berkunjung. Adapun keanekaragaman fauna memiliki keragaman yang tinggi, sehingga bisa digunakan sebagai penunjang ekowisata.Dari hasil penelitian diketahui $68 \%$ pengunjung merasa puas atas kunjungannya karena panorama alam. Hal ini dikaitkan dengan respon masyarakat yaitu $75,7 \%$ baik sekali karena pengembangan objek wisata ini mampu menyediakan peluang pekerjaan.

Persamaan penelitian ini dengan penelitian yang dilakukan oleh Latupapua adalah, mengidentifikasi potensi floraguna sebagai suatu penunjang potensi ekowisata. Sedangkan perbedaan dengan penelitian ini ialah penelitian Latupua di mengambil data respon terhadaap masyarakat sementara penelitian ini lebih mengedepankan potensi pengembangan ekowisata di kawasan Taman Hutan Raya (TAHURA) nipa-nipa di kelurahan watu-watu dengan mewancarai dinas atau instansi yang terkait dalam penelitian ini.

Penelitian yang dilakukan oleh Pramata Indriani, dkk (2013) dalam jurnal Planning for Urban Regional 
and environment, volume 2 yang berjudul "Perencanaan Paket Wisata Kota Manado". Tujuan dari penelitian tersebut adalah untuk mengidentifikasi dan menganalisa potensi wisata yang dimiliki kota Manado.

Hasil penelitian menujukkan dari 26 objek wisata yang ada di Kota Manado didapatkan 18 objek wisata potensial. Untuk mengetahui rute perjalanan wisata potensial digunakan Analisis Keranjang Pasar (Market Basket Analysis) yang terbagi menjadi 3 tahapan, yakni: analisis asosiasi, penggunaan algoritma dan keranjang belanja. Persamaan jurnal tersebut dengan penelitian ini adalah sama-sama menggunakan penelitian yang bersifat deskriptif dan serta mmenganalisa potensi wisatanya. Sedangkan perbedaannya adalah penelitian tersebut dilakukan dengan cara pendekatan kuantitatif, sedangkan dalam penelitian ini menggunakan analisis deskriptif kualitatif

Penelitian Suryawa A, dkk (2015) yang di tulis dalam karya tulis ilmiah berupa jurnal yang berjudul Potensi dan strategi pengembangan Taman Hutan Raya Gunung Tumpa Manado, Sulawesi Utara dalam upaya konservasi keanekaragaman hayati subkawasan Wallacea.

Penelitian tersebut bertujuan untuk menggambarkan potensi Tahura Gunung Tumpa, penggunaan analisis SWOT (Strenghts, Opportunities, Weaknesses, Threats) untuk menentukan strategi pengembangan kawasan yang mendukung konservasi keanekaragaman hayati sub-kawasan Wallacea, manfaat ilmu pengetahuan dan teknologi, kualitas lingkungan,dan visi Kota Manado.

Persamaan penelitian ini dengan penelitian yang dilakukan oleh
Suryawa A,dkk menggambarkan potensi Tahura, Perbedaan penelitian ini dengan penelitian yang dilakukan oleh Suryawa A,dkk adalah penelitian ini terdapat potensi fauna yanga yakni memiliki jenis fauna yang berbeda yang terdapat di tempat penelitian Taman Hutan Raya Gunung Tumpa Manado.

\section{METODE PENELITIAN}

Dalam menyelesaikan penelitian ini, peneliti menggunakan pendekatan deskriptif kualitatif. Artinya, data yang dikumpulkan bukan berupa data angka, melainkan data yang berasal dari naskah wawancara, catatan lapangan, dokumen pribadi, dan dokumen resmi lain yang mendukung. Tujuan menggunakan pendekatan kualitatif adalah agar peneliti dapat menggambarkan serta menuliskan tentang potensi Ekowisata di Kawasan Tahura Nipa-Nipa di Kelurahan WatuWatu.

Penelitian ini dilakukan di bulan maret 2017 dengan lokasi penelitian di kawasan Taman hutan raya (TAHURA) Nipa-Nipa di Kelurahan Watu-Watu. Serta wawancara dan dokumentasi di beberapa Instansi terkait yakni Dinas Pariwisata Provinsi Sulawesi Tenggara, Dinas Kehutanan Unit Pelaksana Daerah (UPTD) Sulawesi Tenggara.

Jumlah informan yang di ambil tergantung dari jumlah replikasi kasus yang di inginkan dengan tujuan menggali informasi dan memiliki kekhususan yang ada yang akan menjadi dasar dari rancangan dan teori yang muncul (moleong, 2000). Mengidentifikasi bahwa penelitian kualitatif diperlukan 6-10 responden (Parse, 2001). 
Adapun informan peneliti mempertimbangkan keterbatasan waktu, tenaga, dan biaya. Adapun informannya sebanyak 6 orang sebagai berikut: (1)Dinas Kehutanan Provinsi Sulawesi Tenggara, Unit Pelaksana Teknis Daerah (UPTD) sebanyak 2 Orang. (2)Kepala Perencanaan dan Anggaran Dinas Pariwisata Provinsi Sulawesi Tenggara sebanyak 1 orang. (3). Masyarakat yang tinggal di sekitar Kawasan Tahura Nipa-Nipa di Kelurahan Watu-Watu sebanyak 3 orang.

Adapun sumber data yang digunakan dalam penelitian ini adalah sebagai berikut: (1) Data Primer, Menurut S. Nasution data primer adalah data yang dapat diperoleh langsung dari lapangan atau tempat penelitian (Moleong,2010:157).

Kata-kata dan tindakan merupakan sumber data yang diperoleh dari lapangan dengan mengamati atau mewawancarai.Peneliti menggunakan data ini untuk mendapatkan informasi langsung tentang potensi pengembangan Ekowisata di kawasan Tahura Nipa-Nipa Kelurahan WatuWatu. Adapun penelitannya yang dii gunakan dapat berupa wawancar, Observasi Langsung, dan Dokumentasi

(2) Sumber data skunder dalam penelitian ini adalah data yang dari instansi-instansi terkait atau lembaga terkait yang relevan dengan penelitian ini meliputi:

(a) Keadaan geografis wilayah Tahura Nipa-Nipa. (b)Data sarana dan prasarana lokasi penelitian. (c)Data/informasi dari Dinas Pariwisata Provinsi Sulawesi Tenggara, Dinas Kehutanan Provinsi dalam, Unit Pelaksana Teknis Daerah (UPTD), serta Masyarakat sekitar yang tinggal dikawasan Tahura Nipa-Nipa di Kelurahan Watu-Watu.

Teknik pengumpulan data yang digunakan dalam penelitian ini antara lain meliputi: 1) Observasi langsung adalah teknik pengumpulan data dengan melakukan pengamatan serta pencatatan secara sistematis terhadap gejala atau fenomena yang ada pada objek penelitian. Obsevasi yang dilakukan di tempat kejadian ataupun tempat penelitian terhadap objek penelitian maksudnya adalah observer ataupun peneliti berada pada objek yang diteliti.Di mana observer atau peneliti turut ambil bagian bersama objek yang diteliti atau di observasi (Moh Pabundu Tika, 2005).

2) Wawancara merupakan metode pengumpulan data dengan cara tanya jawab yang dikerjakan secara sistematis serta berlandaskan terhadap tujuan penelitian (Moh Pabundu Tika, 2005).

Penelitian ini menggunakan wawancara berstruktur dan tidak berstruktur dan tidak berstruktur. Wawancara berstruktur yaitu wawancara dengan terlebih dahulu membuat daftar pertanyaan (Moh Pabundu Tika, 2005), sedangkan wawancara tidak berstruktur dilakukan dengan tanpa menyusun daftar pertanyaan terlabih dahulu akan tetapi peneliti hanya menanyakan garis besar permasalah yang perlu diwawancarai (Moh Pabundu Tika,2005).

3)Dokumentasi dilakukan untuk memperoleh data langsung dari objek yang diteliti akan tetapi melalui pihak lain yakni instansi-instansi terkait ataupun lembaga yang terkait dalam penelitian. Adapun data sekunder berupa perpustakaan, arsip perorangan, 
buku-buku dan lain sebagainya (Moh Pabundu Tika; 2005).

Adapun teknik analisis data yang digunakan untuk menganalisis Potensi Ekowisata di Kawasan Tahura NipaNipa di Kelurahan Watu-Watu pada penelitian ini adalah Menggunakan teknik Analisis model interaktif dimana ada tiga Komponen pokok yang harus dilewati atau dilalui oleh peneliti : 1) penyederhanaan dan abstraksi data yang ada dalam catatan lapangan, reduksi data ini dilakukan selama penelitian berlangsung. Data yang diperoleh dari lapangan jumlahnya cukup banyak, untuk itu maka perlu dicatat secara teliti dan rinci. Semakain lama peneliti dilapangan, maka jumlah data akan semakin banyak dan kompleks. Mereduksi data berarti merangkum dan memilih hal-hal yang pokok. Dalam mereduksi data, setiap peneliti akan dipandu oleh tujuan yang akan dicapai. Tujuan utama penelitian kualitatif adalah pada temuan (Sugiyono, 2010:247).

2)Setelah data direduksi, maka langkah selanjutnya adalah mendisplaykan data atau menyajikan data. Dalam penelitian kualitatif, penyajian data bisa dilakukan dalam uraian singkat, bagan, hubungan antar kategori, flowchart dan sejenisnya.Miles dan huberman dalam sugiyono (2010:249) menyatakan paling sering digunakan untuk menyajikan data dalam penelitian kualitatif adalah dengan teks yang bersifat naratif.

3) Langkah ketiga dalam analisis data kualitatif adalah penarikan kesimpulan dan verifikasi. Kesimpulan awal yang dikemukakan masih bersifat sementara, dan akan berubah bila ditemukan bukti-bukti yang kuat yang mendukung pada tahap pengumpulan data berikutnya. Tetapi apabila kesimpulan dikemukakan pada tahap awaal didukung oleh bukti-bukti yang valid dan konsitensi saat peneliti kembali kelapangan mengumpulkan data, maka kesimpulan yang dikemukakan merupakan kesimpulan yang kredibel, Sugiyono (2010).

Tiga komponen tersebut aktifitasnya berbentuk interaksi dengan proses pengumpulan data berbentuk siklus. Dalam bentuk siklus ini peneliti tetap bergerak diantara tiga komponen pengumpulan data selama proses pengumpulan data berlangsung, sesudah pengumpulan data kemudian bergerak diantara data Reduksi, penyajian data dan penarikan kesimpulan. Untuk lebih jelasnya, proses analisis model interaktif dapat dilihat pada bagan dibawah ini (Sugiyono 2010).

Untuk lebih jelasnya, proses analisis model interaktif dapa dilihat pada bagan dibawah ini (Sugiyono $2010: 247$ )

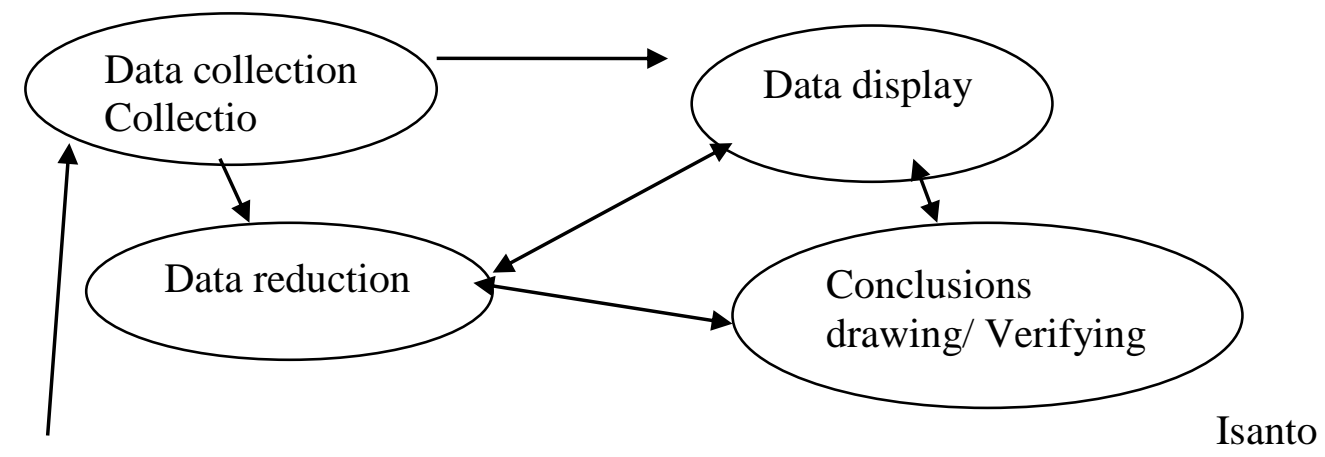


Gambar 1 : Analisis Model Interaktif Sugiyono (2010 : 247).

\section{HASIL DAN PEMBAHASAN}

Kawasan taman hutan Raya Tahura Nipa-Nipa Provinsi Sulawesi tenggara secara geografis terletak antara $03^{\circ} 54^{\prime} 05-03^{\circ} 58^{\prime} 00^{\prime \prime}$ lintang selatatan dan $122^{\circ} 29^{\prime} 38^{\prime \prime}-122^{\circ} 04^{\prime} 25^{\prime \prime}$ Bujur timur sedangkan letak kawasan Tahura Nipa-Nipa secara administratif pemerintah Daerah yaitu terletak pada dua wilayah pemerintah Kabupaten/Kota yakni Kabupaten Konawe dan Kota Kendari provinsi Sulawesi Tenggara.

Secara kewilayahan batas-batas Taman Hutan Raya Nipa-Nipa adalah sebagai berikut:

1) Sebelah utara berbatasan dengan teluk Lasolo Laut banda dan pemukiman masyarakat kecamatan soropia dan Kecamatan Lalonggasumeeto Kabupaten Konawe.

2) Sebelah Timur berbatasan dengan Tanjung Nipa-Nipa, Laut Banda dan pemukiman Masyarakat Kecamata Soropia Kabupaten Konawe.

3) Sebelah Barat berbatasan dengan kecamatan Mandonga Kota Kendari.
4) sebelah selatan berbatasan dengan Teluk kendari dan Pemukima Masyarakat kecamatan kendari barat, Kendari, dan Kecamatan Mandonga.

Luas Kawasana Hutan Taman Hutan Raya (TAHURA) Nipa-Nipa merupakan Kawasan pelestarian Alam (Hutan Konsevasi) di Provinsi Sulwawesi Tenggara dengan luas 7.877,5 Ha.

Dalam wilayah administratif pemerinthan terletak di kabupaten Konawe seluas 5.574,9 Ha dan Kota Kendari seluas 2.302,6 Ha berdasarkan Lokasi kewilayahan tersebut Kawasan Kawasan Tahura Nipa-Nipa lebih luas berada di konawe sebesar $71 \%$ dan Kota Kendari sebesar 29\%.

Kawasan tahura Nipa-Nipa terletak antara ketinggian $25 \mathrm{~m}-100 \mathrm{~m}$ dpl dan topografi landai sehingga sangat curam (bergunung) kemiringan lereng berkisar antara $8 \%$ sampai $40 \%$ $172,40 \mathrm{~mm}$. 


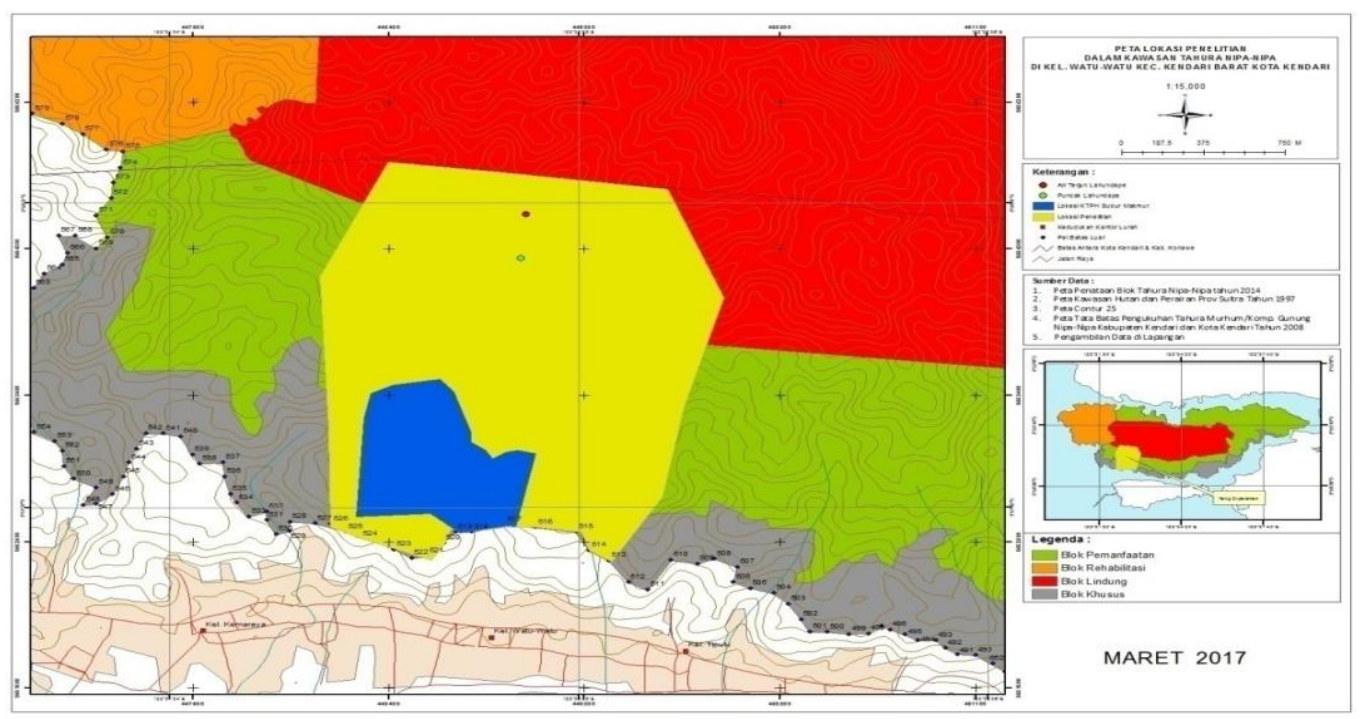

Gambar 2. Lokasi Penelitian

Dalam Kawasan Tahura NipaNipa khususnya di keluruhan WatuWatu pada dasarnya belum terdapat fasilitas yang memadai, akan tetapi terdapat papan informasi guna memudahkan pengunjung untuk mengetahui lokasi obyek wisata. Untuk memudahkan aksebilitas para pengunjung yang ingin berwisata terdapat papan informasi keterangan obyek wisata.Papan informasi yang terbuat dari bahan besi dan berwarna dasar hijau.

Pos jaga di Kawasan Tahura NipaNipa Kelurahan Watu-Watu di kenal

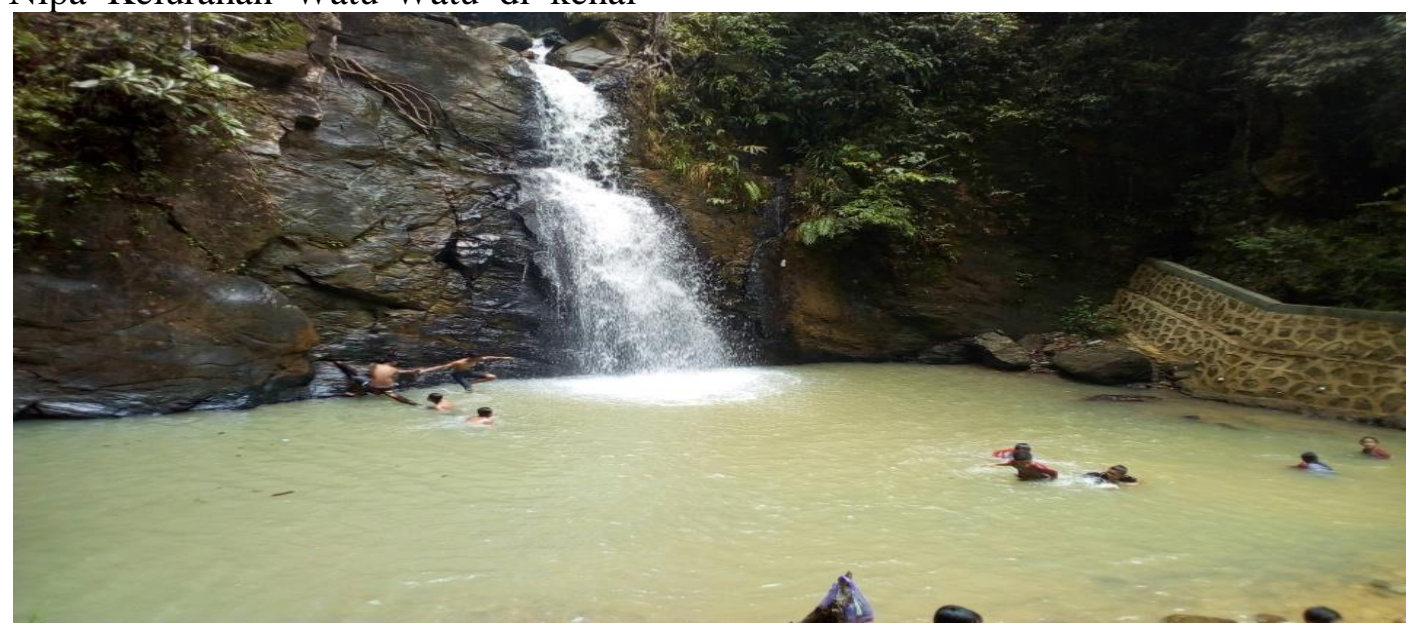

Gambar 3. Air Terjun Lahundape dengan pos jaga Lahundape.Pos jaga yang terletak di lorong kodya ini di bangun untuk menjaga keamanan Kawasan Tahura Nipa-Nipa di Kelurahan Watu-Watu. Selain menjaga keamana pos jaga tersebut juga merupakan sarana informasi langsung bagi pengunjung untuk mengetahui secara langsung wisata apa saja yang ada di dalam kawasan Tahura NipaNipa di Kelurahan Watu-Watu dengan menanyakan Petugas yang bertugas di pos jaga.
Air Terjun Lahundape yang biasa di kenal dengan air terjun amarilis oleh masyarakat sekitar yang tinggal di 
sekitar Kawasan ataupun pengunjung yang datang merupakan air terjun indah serta terbesar dari beberapa air terjun yang ada di Kawasan Tahura Nipa-Nipa di Kota Kendari yang terdapat dalam Kawasan Tahura NipaNipa di Kelurahan Watu-Watu. Air Terjun yang memiliki tinggi $\pm 9,5$ meter dan lebar 14 meter serta panjang 15 meter ini merupakan obyek wisata yang menarik. Air terjun terbentuk secara alami menyerupai kolam serta memiliki air yang sejuk. terjun, yakni air terjun Lahundape.Air terjun ini biasanya ramai oleh anak sekolah Maupun Mahasiswa.Berdasarkan observasi langsung di lakukan oleh peneliti. Kawasan Air Terjun Lahundape memang benar adanya dan sering di kunjungi oleh pengunjung.

Dalam Kawasan Tahura Nipa-Nipa terdapat obyek wisata alam berupa air

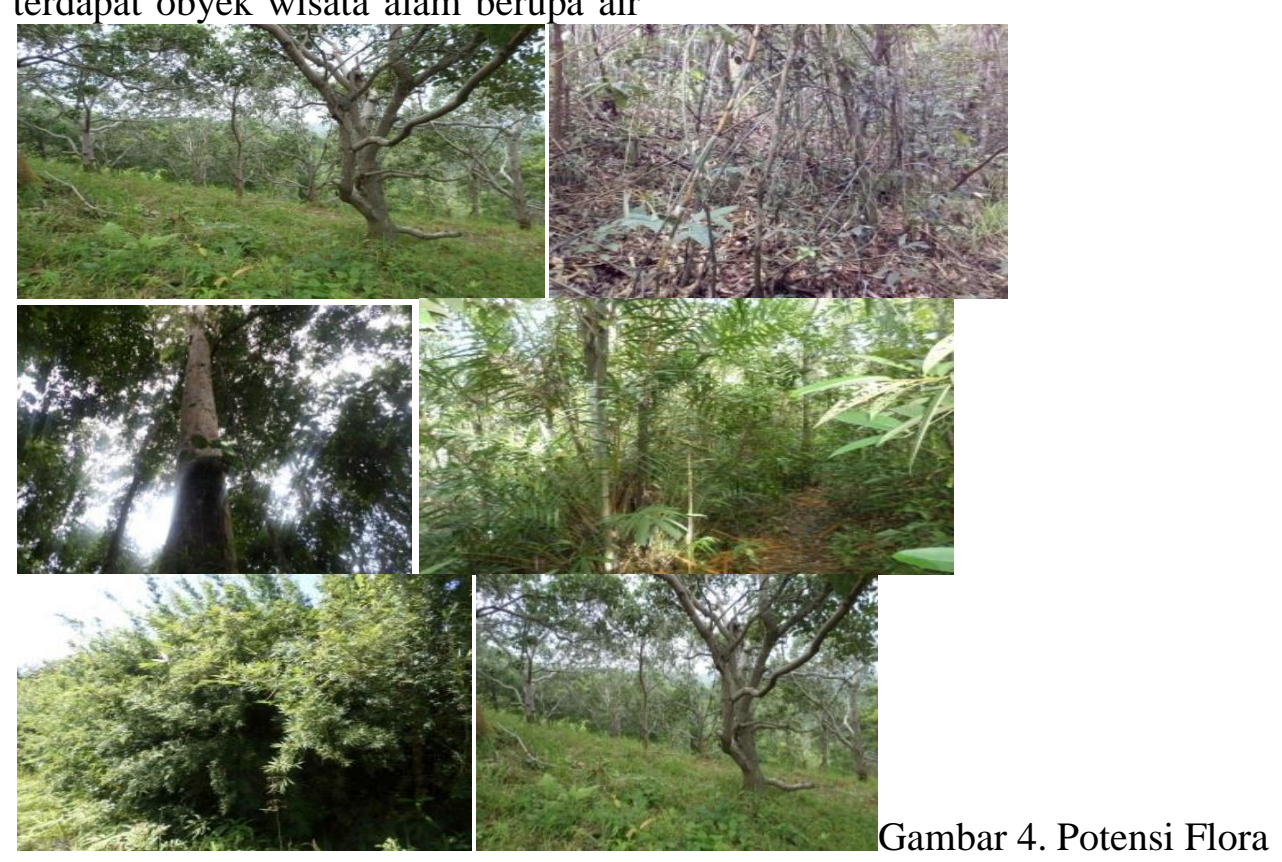

Dalam Kawasan Tahura Tahura Nipa-Nipa Kelurahan Watu-Watu memiliki keanekaragaman hayati berupa Flora.Bila kita mengunjungi kawasan Tahura Nipa-Nipa di Kelurahan Watu-Watu kita dapat dengan dengan mudah menjumpai tumbuhan-tumbuhan yang ada, beberapa tumbuhan yang telah teridentifikasi baik itu berupa tumbuhan tinggi maupun tumbuhan rendah. Tumbuhan tinggi seperti kayu besi (Metrosideros petiolata), Eha (Castanopsis Buruana BL), Jambujambu (Eugenis Sp), Bolo-Bolo (Adenandera celebica), Sedangkan untuk tumbuhan rendah berupa Bambu (Bambusa SP), Pandan Hutan (Pandanus Sp), Palem (Pinaraga Caesia), selain itu ada tumbuhan 
menarik berupa tumbuhan Puta (Baringtonia Recemosa).

$\begin{array}{lcr}\text { Diantara beberapa } & \text { jenis } \\ \text { tumbuhan yang ada } & \text { serta } \\ \text { teridentifikasi } & \text { terdapat } & \text { beberapa }\end{array}$ tumbuhan endemik sulawesi, artinya beberapa tumbuhan tersebut hanya ada di pulau sulawesi dan tidak terdapat di Kawasan lain adapun jenis tumbuhan endemik Sulawesi berupa Kayu Besi, Kalapi, Bolo-Bolo. Serta terdapat beberapa jenis anggrek yang belum teridentifikasi yang memiliki daya tarik tersendiri serta berbeda dengan yang ada di daerah lain.

Beberapa jenis hewan endemik Sulawesi yang terdapat di Kawasan Taman Hutan Raya (TAHURA) Nipa-
Nipa berupa Monyet tidak berekor, Kus-Kus, dan Biawak. Artinya bahwa hewan tersebut tidak ada di daerahdaerah lain. Sehingga memiliki potensi bila di kembangkan untuk menarik para pengujunjung/Wisatawan.

Untuk beberapa hewan seperti monyet macaca, babi hutan, capung biasanya masyarakat masih jumpai di kawasan Tahura Nipa-Nipa di Kelurahan Watu-Watu.Berdasarkan hasil penelitian selama berada dilapangan di Kawasan Tahura NipaNipa di Kelurahan Watu-Watu, masih ditemukan beberapa jenis hewan/satwa.Hewan yang masih di jumpai berupa Babi hutan, Monyet, capung, dan beberapa jenis ular.

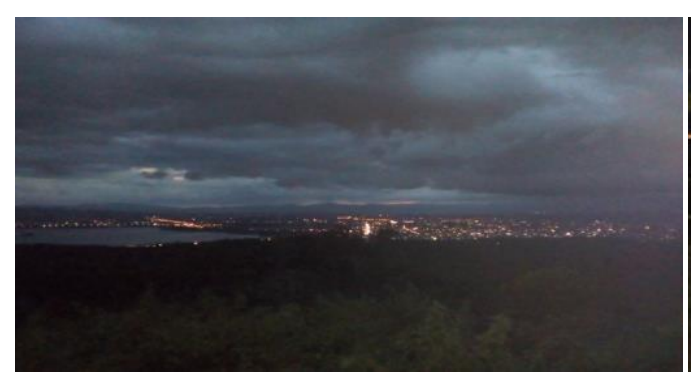

Gambar 5. Camping Ground

Selain memiliki air terjun lahundape dalam Kawasan Tahura Nipa-Nipa di Kelurahan Watu-watu juga terdapat puncak dan bumi perkemahan Lahundape, Bumi Perkemahan berada pada titik koordinat S $03^{\circ} 56^{\prime} 5^{\prime \prime}$ E $122^{\circ} 32^{\prime} 0^{\prime \prime}$. kelembaban lingkunga beraada pada kisaran 68-78 artinya kelembaban lingkungan mencapai $68 \%$ pada pagi hari dan akan mencapai sekitar $78 \%$ pada siang hari. Suhu lingkungan berada dikisaran $23^{\circ} \mathrm{C}-28^{\circ} \mathrm{C}$ artinya di pagi hari suhu udara sekitar $23^{\circ} \mathrm{C}$ dan bisa mencapai sampai $28^{\circ} \mathrm{C}$ pada siang hari.

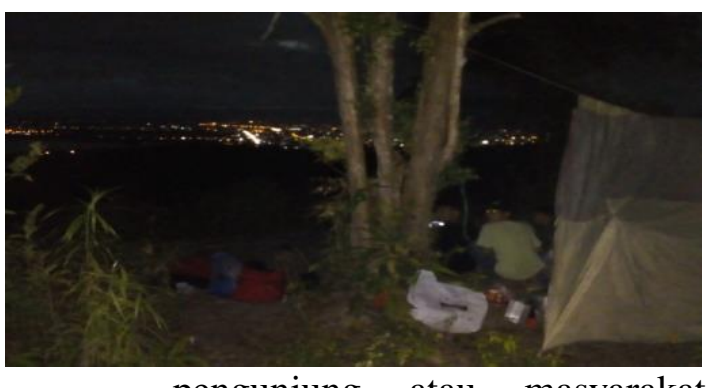

pengunjung atau masyarakat sekitar lebih mengenal dengan puncak viktor. Pengunjung yang biasanya datang merupakan kalangan remaja dan kelompok pecinta lingkungan yang gemar berkemah. Para pekemah akan datang khususnya pada hari libur. Tujuan pengunjung yang datang dipuncak viktor untuk menikmati pemandangan kota kendari. Maksud pernyataan di atas dalam Kawasan Tahura Nipa-Nipa yang ada di Kelurahan Watu-Watu terdapat tempat camping, di mana tempat camping yang lebih di kenal oleh masyarakat dengan puncak Amarilis. Sedangkan Pemerintah yakni pihak Kehutanan Sulawesi Tenggara Menyebut Kawasan tersebut sebagai Puncak dan Bumi perkemahan Lahundape. 


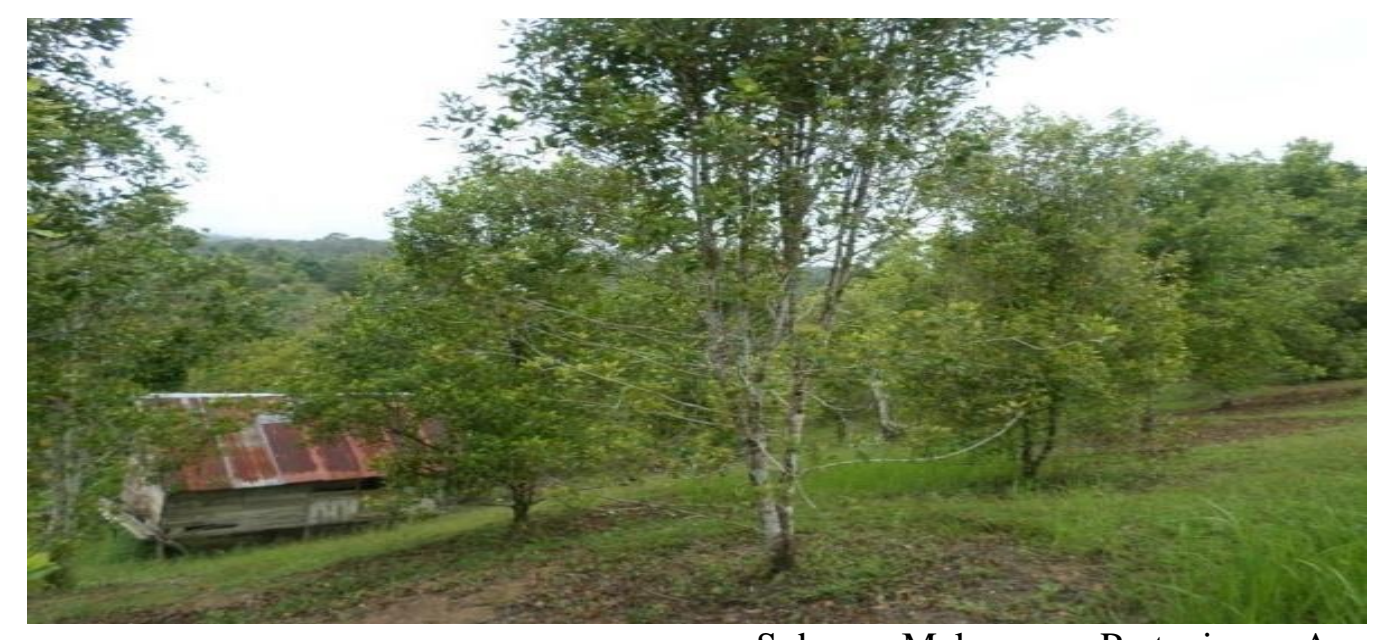

Gambar 6. Lahan Pertanian

Dalam Kawasan Tahura Nipa-

Nipa di Kelurahan Watu-Watu terdapat lahan pertanian yang terbentuk dalam kelompok. Petani di Kawasan Tahura Nipa-Nipa di Kelurahan Watu-Watu .kelompok petani lebih di kenal dengan Kelompok Tani Pelestari Hutan (KTPH) Subur Makmur. KPH Subur Makmur lokasinya berada pada titik koordinat S $03^{\circ} 57^{\prime} 12.4^{\prime \prime}$ E 12232'18.6”.KTPH Subur Makmur Beranggotakan dari 34 orang.Luas lahan KTPH Subur Makmur \pm 35 Ha.Tanaman yang di Tanami di Lahan KTPH Subur Makmur umumnya merupakan tanaman Jangka Panjang seperti cengkeh, jambu mete, rambutan, pala, durian.KTPH Subur Makmur terbentuk pada tahun 2003.

Lahan pertanian KTPH Subur Makmur cukup potensial untul di jadikan sebagai wisata Agro atau wisata pertanian. Hal ini di sebabkan karena letak lahan pertanian KTPH Subur Makmur sangat dekat dengan kota Kendari. Sehingga sangat strategis untuk di jadikan tempat wisata maupun wahana pembelajaran pendidikan, Jadi bila kita memasuki Kawasan Tahura Nipa-Nipa di Kelurahan Watu-Watu kita akan menemukan lahan pertanian KTPH
Subur Makmur. Pertanian Agro umumnya berada di wilayah pedesaan sedangkan Lahan pertanian Yang ada di Kawasan Tahura Nipa-Nipa di Kelurahan Watu-Watu merupakan lahan pertanian yang ada di dalam Kota Kendari.Berdasarka hasil observasi yang dilakukan dikawasan tahura Nipa-Nipa terdapat lahan pertanian masyarakat yang secara hukum di akui keberadaannya yakni lahan pertanian Kelompok Tani Pelestari Hutan (KTPH) Subur Makmur.

\section{KESIMPULAN}

Berdasarkan pemaparan dan pembahasan hasil penelitian dapat disimpulkan, terdapat Potensi Ekowisata di kawasan Tahura NipaNipa di kelurahan Watu-Watu berupa:1) Terdapat Potensi Wisata alam yang sangat menjanjikan bila dikembangkan dengan baik. Adapun potensi wisata alam yang dapat dikembangkan berupa air terjun Lahundape dan bumi perkemahan Lahundape.

2) Selain dari wisata alam terdapat juga Daya tarik lain berupa flora yang berada dikawasan Tahura Nipa-Nipa di Kelurahan Watu-Watu. Jenis Flora Yang ada di Kawasan Tahura NipaNipa memiliki keberagaman baik dari 
jenis tumbuhan endemik yang ada berupa Kayu Besi, Bolo-Bolo, dan Kalapi dan Fauna Endemik berupa Monyet Tidak Berekor, Biawak, KusKus.

3) Selain Potensi Ekowisata yang terdapat di kawasan tahura Nipa-Nipa di Kelurahan Watu-Watu terdapat juga potensi lain. Yakni Potensi agro wisata.Potensi agrowisata yang ada di kawasan Tahura Nipa-Nipa di Kelurahan Watu merupakan konsep pertama yang ada di di Indonesia.Karena umumnya Agrowisata berada di daerah Pedesaan.

\section{DAFTAR PUSTAKA}

\section{BKSDA SULTRA.(2002) Informasi Kawasan Konservasi Kendari: Balai Konservasi Sumber Daya Alam Sultra.}

Damanik, J, dan Weber F Helmut. (2006). Perencanaan Ekowisata; Dari Teori KeAplikasi. Yogyakarta: Pusat Pariwisata UGM dan ANDI.

Fandeli, C. (2000). Pengusahaan ekowisata. Yogyakarta: Fakultas Kehutanan UGM.

Latupapua, Y., Th. 2008. Studi Potensi Kawasan dan Pengembangan Ekowisata di Tual Kabupaten Maluku Tenggara. Jurnal Ichsan Gorontalo. Volume 3. No 1 Februari- April. 1360 1375.

Marpaung, Happy, 2002.Pengetahuan Pariwisata edisi revisi. Alfabeta, Bandung.

Moleong, L.J. 2000. Metodologi Penelitian
Kualitatif. Bandung: Remaja Rosdakarya.

Mohhamad Baiquni. 2001 Ekowisata Kawasan Karst.Belajar dari Guilin Cina untuk Pengembangan Wisata di Wonogiri.Pelatihan

Pengelolaan Kawasan Karst Kabupaten

Wonogiri.Wonogiri Juni 2001.

Moh Pabudu Tika. 2005. Metode Penelitian Geografi. Jakarta: Bumi Aksara.

Pramata, indriani dkk.2013. Perencanaan Paket Wisata Kota Manado. Malang, Universitas Brawijaya.

Sugiono. 2010. Metode Penelitian Kuantitatif, Kualitatif dan $R$ $\& D$. Bandung: Alfabeta.

Suwantoro, G. 1997. Dasar-Dasar Pariwisata.ANDI.Yogyakarta

Wood, Megan E. 2002. Ecotourism Principles, Practies \& Policies for Sustainability.

Artikel.United Nations Environment Programe Divition of Technology, Industry and Economics.Paris. Diakses 30 desember 2016 

